\title{
KONSEP QUR'ANI DALAM PEMIKIRAN TASAWUF IBNU QAYIM AL-JAUZIYAH
}

\author{
Qur'anic's Concept in Tasawuf thinking Of Ibnu Qayyim Al-Jauziyah
}

\author{
Marhaban \\ Institut Agama Islam Negeri Langsa \\ Hajimarhaban1705@yahoo.com
}

\begin{abstract}
The attitude of seclusion from worldly life is absolute prerequisite for achieving a high spiritual experience. This is based on the fait that love of the excessive world will lead to contamination and destruction of spiritual originality on human psyche. It can notbe denied that being closer to God by understanding the Qur'an has implications for individual piety. By using the study of Sufism's figures namely Ibn Qayyim Al-Jauziyah, this article found the fact that Ibn Qayyim Al-Jauziyah used the Qur'an as a concept of sufism teachings. There are three concepts of Sufism offered by Ibn Qayyim, First, Taking As Many Benefits as possible from the Qur'an, Second, Contemplating the Content of the Koran, and third, Health of heart and mind.
\end{abstract}

Keywords : Concept, Qura'ani, Sufism

\begin{abstract}
Abstrak
Sikap pengasingan dari kehidupan dunia adalah prasyarat mutlak untuk mencapai pengalaman spiritual yang tinggi. Hal ini didasarkan pada kecintaan pada dunia yang berlebihan akan menyebabkan kontaminasi dan penghancuran orisinalitas spiritual pada jiwa manusia. Tidak dapat dipungkiri dengan menjadi lebih dekat dengan Tuhan dengan memahami Alquran memiliki implikasi bagi kesalehan individu. Dengan menggunakan studi tokoh sufi yaitu Ibnu Qayyim Al-Jauziyah, artikel ini menemukan fakta bahwa Ibnu Qayyim Al-Jauziyah menggunakan Alquran sebagai konsep ajaran tasawunya. Ada tiga konsep Tasawuf yang ditawarkan oleh Ibnu Qayyim, Pertama, Mengambil Manfaat Sebanyak-banyaknya dari Alquran, Kedua, Merenungkan Kandungan Alquran, dan ketiga, Kesehatan hati dan akal.
\end{abstract}

Kata Kunci : Konsep, Alquran, Sufisme 


\section{Pendahuluan}

Pada zaman sekarang, banyak orang diberbagai kalangan masyarakat mengejar kemewahan dunia, dan berlebih-lebihan dalam mencintai keindahannya seolah-olah akan hidup selamanya. Namun, pada akhirnya mereka menyesal setelah mendapatkan musibah dan timbul kesadaranbahwa kesenangan dunia itu sementara dan tidak bisa membuat orang tenang dan tenteram. Dengan demikian, mereka mancari ketenangan dan kedamaian yang dibutuhkan melalui sentuhan-sentuhan spiritual atau rohani yang bisa diperoleh dengan mendekatkan diri kepada Sang Pencipta.

Dalam tulisan ini penulis mencoba membahas tentang dasar atau landasanlandasan yang sering digunakan oleh para sufi dalam bertasawuf. Landasan Alquran merupakan acuan pokok yang selalu dijadikan oleh umat Islam untuk berbuat dan bertindak.

Dalam menjalankan kehidupan sehari-hari muncul berbagai pertanyaan seputar landasan atau dasar seseorang dalam berbuat suatu hal, termasuk dalam persoalan tasawuf. Oleh sebab itu, landasan atau dasar-dasar tasawuf dalam Alquran dan Hadis urgen untuk diteliti lebih lanjut guna menjawab pertanyaan-pertanyaan tersebut.

\section{Konsep Qur'ani dalam Tasawuf}

Konsep berasal dari bahasa latin,yang secara harfiah berartitangkapan, rancangan, pendapat, ide atau gagasan ${ }^{1}$. Sedang menurut istilah, konsepmemiliki beberapa arti, di antaranya: 1) kegiatan atau proses berfikir; 2) dayaberfikir, khususnya penalaran dan pertimbangan; 3)produk proses berfikir, sepertiide, angan-angan, atau penemuan; dan 4) produk intelektual atau pandangan.

Konsep dapat dilihat dari dua segi, subjektif dan objektif. Dari segisubyektif, konsep merupakan suatu kegiatan intelek untuk menangkap sesuatu.Sedangkan dari segi objektif, konsep merupakan sesuatu yang ditangkap olehkegiatan intelek tersebut.Jika konsep dinyatakan dalam bentuk kata atau serangkaian kata-kata, makakonsep itu akan menjadi term. Term tidak harus muncul dalam bentuk satu kata, tapidapat pula berbentuk frase ${ }^{2}$. Pengertian itulah yang dimaksud tulisan ini, yaitu konsep sebagai ide, hasil berfikir dan pemahaman, serta produk intelektual.

Tasawuf dari segi bahasa mempunyai sejumlah kata yang dikait-kaitkan oleh para ahli untuk menjelaskannya. Abudin Nata menyebutkan lima istilah yang berkenaan dengan tasawuf, yaitu: ahlal-Suffah (para muhajirin Mekah yang tinggal di serambi Mesjid Rasulullah saw), Saff (barisan), Safa (suci, bersih), sophos (bahasa Yunani) orang yang menpunyai jiwa yang senantiasa cenderung mencari kebenaran ketuhanan, dan Suf(bulu domba) ${ }^{3}$.

Alquran merupakan kitab Allah yang didalamnya terkandung muatan-muatan ajaran Islam, baik akidah, syarah maupun muamalah. Ketiga muatan tersebut banyak

\footnotetext{
${ }^{1}$ Departemen Pendidikan, Kamus Besar Bahasa Indonesia, (Balai Pustaka, 1990), h. 725

${ }^{2}$ Komaruddin dan Yooke Tjuparmah S. Komaruddin, Kamus Istilah Karya Tulis Ilmiah, h. 122.

${ }^{3}$ Abuddin Nata, Akhlak Tasawuf Cet. I, (Jakarta; RajaGrafindo Persada, 2006), h.179.
} 
tercermin dalam ayat-ayat yang termaktub dalam Alquran. Ayat-ayat Alquran di satu sisi memang ada yang perlu dipahami secara konstektual-rohaniah. Jika dipahami secara lahiriah saja, ayat-ayat tersebut akan terasa kaku, kurang dinamis, dan tidak mustahil akan ditemukan persoalan yang tidak dapat diterima secara psikis ${ }^{4}$.

Secara umum ajaran Islam mengatur kehidupan yang bersifat lahiriah dan batiniah. Pemahaman terhadap unsur kehidupan yang bersifat batiniah pada gilirannya nanti melahirkan tasawuf. Unsur kehidupan tasawuf ini mendapat perhatian yang cukup besar dari sumber ajaran Islam yaitu Alquran dan hadis serta praktik kehidupan Nabi dan para sahabatnya ${ }^{5}$.

\section{Ayat Alquran tentang tasawuf secara eksplisit}

Makna eksplisit adalah makna absolut yang langsung diacu oleh bahasa. Konsep makna ini bersifat denotatif (sebenarnya) sebagai representasi dari bahasa kognitif. Eksplisit: makna atau maksud yang diajukan secara langsung dan jelas

Makna eksplisit mengacu pada informasi, sedangkan makna implisit mengacu pada emosi. ${ }^{6}$ Dalam Q.S. Al-Maidah ayat : 54

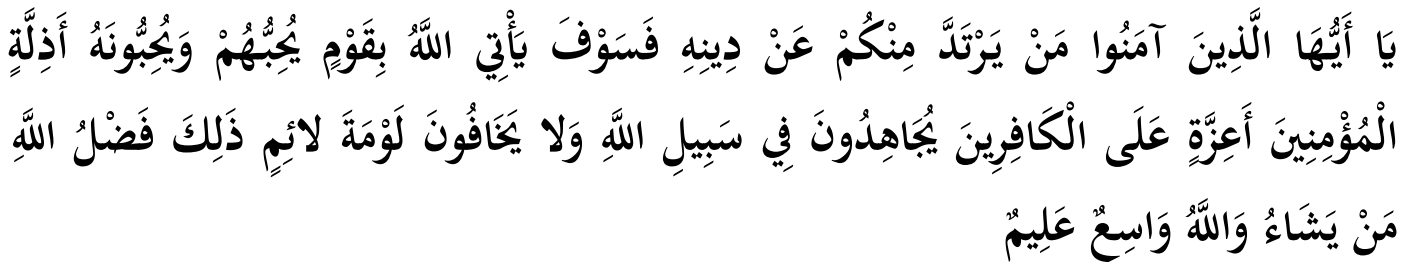

Artinya ; "Hai orang-orang yang beriman, barangsiapa di antara kamu yang murtad dari agamanya, Maka kelak Allah akan mendatangkan suatu kaum yang Allah mencintai mereka dan merekapun mencintaiNya, yang bersikap lemah Lembut terhadap orang yang mukmin, yang bersikap keras terhadap orang-orang kafir, yang berjihad dijalan Allah, dan yang tidak takut kepada celaan orang yang suka mencela. Itulah karunia Allah, diberikan-Nya kepada siapa yang dikehendaki-Nya, dan Allah Maha luas (pemberianNya), lagi Maha Mengetahui”. (Q.S. Al-Maidah [5] : 54).

Ayat diatas secara ekplisit menjelaskan ciri-cirialiran tasawuf sebagai berikut ${ }^{7}$ :

a. Allah mencintai mereka dan merekapun mencintai Allah.

b. Bersikap lemah lembut terhadap orang-orang mukmin dan bersikap tegas terhadap orang-orang kafir.

Sifat ini merupakan hasil kecintaan kepada Allah. Seorang yang cinta kepada Allah akan menjadi seorang yang arif lagi bijaksana yang akan selalu gembira dan senyum, bersikap lemah lembut karena jiwanya dipenuhi oleh sifat Allah yang paling dominan, yaitu rahmat dan kasih sayang. Inilah yang menghasilkan

${ }^{4}$ https://syairiblog.blogspot.co.id/2015/04/makalah-islam-dan-tasawuf.htmltanggal 6 Februari 2018.

${ }^{5}$ Rosihon Anwar dan Mukhtar Solihin, Ilmu Tasawuf, (Bandung : Pustaka Setia, 2006), h.16.

${ }^{6}$ Rosihon Anwar dan Mukhtar Solihin, Ilmu Tasawuf, h. 22

${ }^{7}$ Rosihon Anwar dan Mukhtar Solihin, Ilmu Tasawuf,h. 25. 
rasa persaudaraan seagama, yang menjadikannya bersikap toleran terhadap kesalahannya, lemah lembut dalam sikap dan perilakunya termasuk ketika menegur atau menasehati. Sikap ini yang mengantar seorang muslim merasakan derita saudaranya, sehingga memenuhi kebutuhannya dan melapangkan kesulitannya. Sedang sikap tegas kepada orang-orang kafir, bukan berarti memusuhi pribadinya, atau memaksakan mereka memeluk Islam, atau merusak tempat ibadah dan menghalangi mereka melaksanakan tuntutan agama dan kepercayaan mereka tetapi bersikap tegas, terhadap permusuhan mereka dan upaya-upaya mereka melecehkan ajaran agama dan kaum muslimin.

c. Mereka berjihad di jalan Allah

Jihad disini tidak terbatas dalam bentuk mengangkat senjata, tetapi termasuk upaya-upaya membela islam dan memperkaya peradabannya dengan lisan dan tulisan, sambil menjelaskan ajaran Islam dan menangkal ide-ide yang bertentangan dengannya lebih-lebih yang memburukannya.

d. Tidak takut kepada celaan pencela

Mereka tidak takut dicela bahwa mereka tidak toleran misalnya jika mereka bersikap tegas terhadap orang kafir yang memusuhi islam, tidak juga khawatir dituduh fanatik atau fundamentalis jika menegakkan ukhwah islamiah ${ }^{8}$.

Dari ayat diatas para ahli sufi menafsirkannya bahwa akan datang suatu kaum yang dicintai Allah dan mereka juga mencintai Allah, sebagaimana yang tercantum didalam Tafsir al-Misbah karangan Quraish Shihab bahwa Allah mencintai mereka dan merekapun mencintai Allah. Cinta Allah kepada hamba-Nya dipahami para mufasir dalam arti limpahan kebaikan dan anugerah-Nya. Cinta Allah dan karunianya tidak terbatas dan cinta manusia kepada Allah bertingkat-bertingkat, tetapi yang jelas adalah cinta kepada-Nya merupakan dasar dan prinsip perjalanan menuju Allah, sehingga semua peringkat (maqām) dapat mengalami kehancuran kecuali cinta. Cinta tidak bisa hancur dalam keadaan apapun selama jalan menuju Allah tetap ditelusuri ${ }^{9}$.

Bahwa Allah memerintahkan manusia agar senantiasa bertaubat membersihkan diri dan memohan ampunan kepada-Nya sehingga memperoleh cahaya dari-Nya.Hal ini sesuai dengan Q.S. at-Tahrim ayat 8 yaitu:

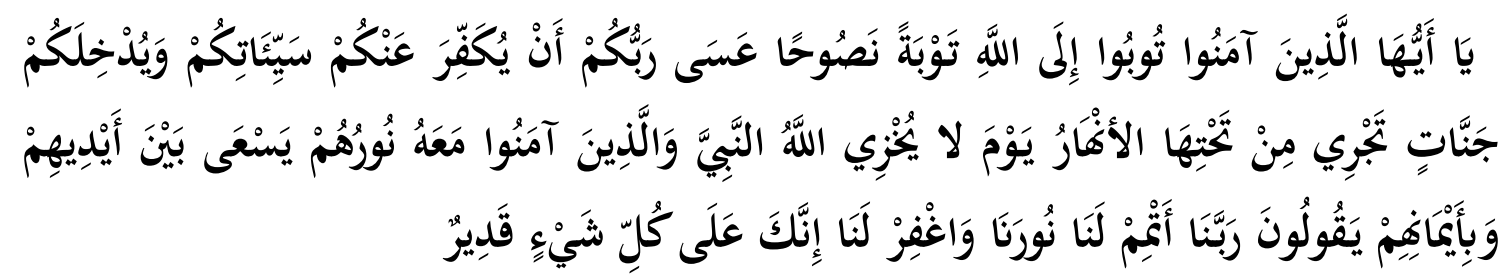

Artinya:'Hai orang-orang yang beriman, bertaubatlah kepada Allah dengan taubat yang sebenar-benarnya, mudah-mudahan Tuhanmu akan menghapus kesalahan-kesalahanmu dan memasukkan kamu ke dalam surga yang mengalir dibawahnya sungai-sungai, pada hari ketika Allah tidak

${ }^{8}$ Rosihon Anwar dan Mukhtar Solihin, Ilmu Tasawuf, h. 122.

${ }^{9}$ Quraish Shihab, Tafsir al-Misbah, (Jakarta : Lentera Hati, 2001), h. 121. 
menghinakan Nabi dan orang-orang beriman bersama dengan dia ; sedang cahaya mereka memancar dihadapan dan disebelah kanan mereka, sambil mereka mengatakan,"Ya Tuhan kami, sempurnakanlah bagi kami cahaya kami ; sesungguhnya Engkau Maha Kuasa atas segala sesuatu." (QS. AtTahrim [66] : 8)

Dari ayat tersebut dijelaskan bahwa seseorang yang bertasawuf harus bertaubat lebih dulu untuk menghapus segala kesalahan-kesalahan yang pernah dilakukan sebelumnya. Para sufi berpendapat bahwa untuk mencari keridhaan Allah harus bertaubat lebih dahulu dan meninggalkan segala yang menyangkut dengan kebendaan (dunia) dan menghiasinya dengan akhlak terpuji.Dengan demikian,seseorang bisa menuju keridhaan Allah SWT.

Dalam tasawuf, kata taubat berasal dari kata tāba-yatūbu-taubatan yang artinya kembali. Sebagaimana dikutip oleh Jalāluddin Rahmat dari kitab Manājil Al-sāirīn bahwa taubat adalah maqām yang kedua. Sedangkan maqām yang pertama adalah yaqzah atau kesadaran ${ }^{10}$. Dalam yaqzah itu, seseorang tiba-tiba disadarkan oleh Allah SWT akan keburukan-keburukan yang pernah ia lakukan selama menjauh dari Allah SWT. Bisa jadi ia disadarkan dengan satu musibah yang menimpanya atau nasihat orang lain dan perenungannya sendiri. Allah mempunyai cara untuk menyadarkan hamba-Nya. Tetapi dalam tasawuf bahkan menurut Alquran, orang lebih banyak disadarkan oleh musibah ${ }^{11}$.

Allah juga menegaskan dalam Alquran tentang pertemuan manusia dengan Allah sebagaimana yang tercantum Q.S. al-Baqarah ayat 115 , yaitu:

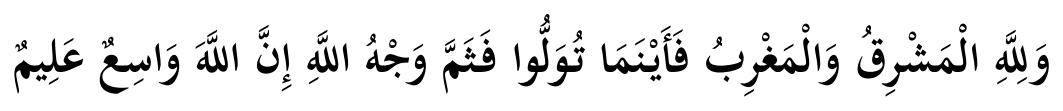

Artinya: "Dan kepunyaan Allah-lah timur dan barat, maka kemanapun kamu menghadap disitulah wajah Allah. Sesungguhnya Allah Maha luas (rahmatNya) lagi Maha Mengetahui." (QS. Al-Baqarah [2] : 115)

Bagi kaum sufi ayat tersebut mengandung arti bahwa dimana Tuhan ada, di situ pula Tuhan dapat dijumpai. Maksudnya kapanpun dan dimanapun kita berada Allah selalu bersama kita karena dzat-Nya tidak dibatasi ruang dan waktu dan tidak pula dibatasi oleh tempat.

Dalam Alquran juga dijelaskan tentang kedekatan manusia dengan-Nya seperti yang tercantum dalam Q.S. al-Baqarah ayat 186, yaitu:

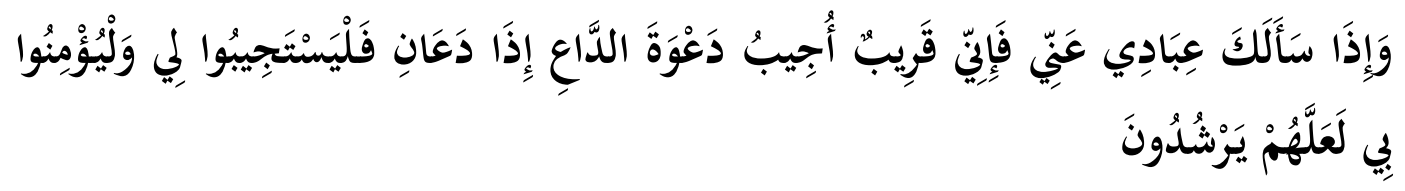

\footnotetext{
${ }^{10}$ Anwar, Ilmu Tasawuf, h.78.

${ }^{11}$ Jalaluddin Rahmat, Meraih Cinta Ilahi ; Pencerahan Sufistik, (Bandung : Remaja Rosdakarya, 2001), h. 8 .
} 
Artinya:"Jika hamba-hamba-Ku bertanya kepadamu tentang diri-Ku, Aku adalah dekat, Aku mengabulkan seruan orang yang memanggil jika ia panggil Aku'. (QS. Al-Baqarah [2] : 186).

Dalam Q.S. Qaf ayat 16 juga disebutkan, yaitu:

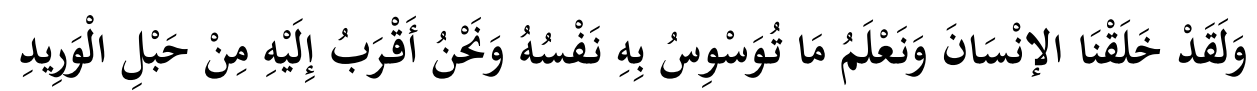

Artinya:"Sebenarnya Kami ciptakan manusia dan Kami tahu apa yang dibisikkannya kepadanya, Kami lebih dekat kepadanya daripada pembuluh darahnya sendiri'. (QS. Qaf [50] :16)

\section{Ayat Alquran Tentang Tasawuf Secara Implisit}

Makna implisit adalah makna universal yang disembunyikan oleh bahasa. Konsep makna ini bersifat konotatif (kias) sebagai representasi dari bahasa emotif. Implisit: makna atau maksud yang diajukan tidak secara langsung dan sembunyi-sembunyi ${ }^{12}$.

Ada pun ayat-ayat Alquran yang menjadi landasan tasawuf secara inplisit dapat dilihat dari tingkatan (maqām) dan keadaan (ậwăl) para sufi yaitu :Tingkatan Zuhud yakni tercantum dalam Q.S. An-Nisaa' ayat 77 yaitu : "Katakanlah kesenangan didunia ini hanya sementara dan akhirat itu lebih baik untuk orang-orang yang bertakwa..."

a. Tingkatan Tawakkal yaitu dalam surah At-Thalak ayat 3 yaitu:

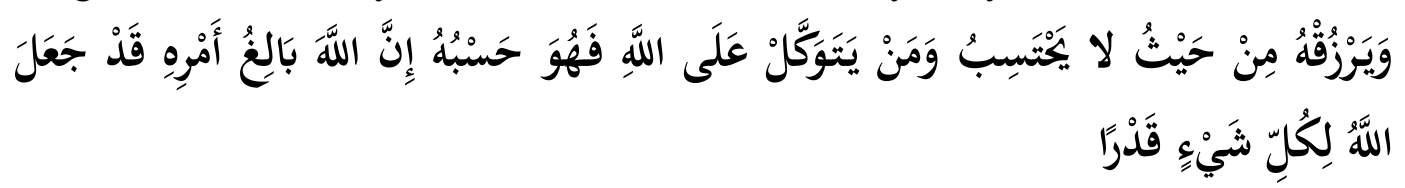

Artinya: "Dan memberinya rezeki dari arah yang tiada disangka-sangkanya. Dan barang siapa yang bertawakal kepada Allah niscaya Allah akan mencukupkan (keperluan) nya. Sesungguhnya Allah melaksanakan urusan (yang dikehendaki) Nya. Sesungguhnya Allah telah mengadakan ketentuan bagi tiap-tiap sesuatu". (QS. At-Thalak [65] : 3)

b. Tingkatan Syukur dalam Q.S. Ibrahim ayat 7 yaitu;

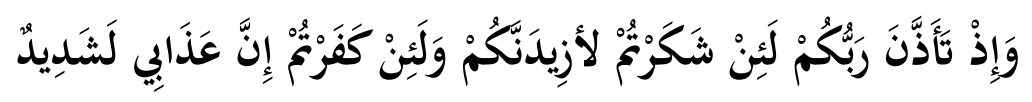

Artinya: "Dan (ingatlah juga), tatkala Tuhanmu memaklumkan: "Sesungguhnya jika kamu bersyukur, pasti Kami akan menambah (nikmat) kepadamu, dan jika kamu mengingkari (nikmat-Ku), maka sesungguhnya azab-Ku sangat pedih". (QS. Ibrahim [14] : 7)

c. Tingkat Sabar berlandaskan Q.S. Al-Baqarah ayat 155 yaitu:

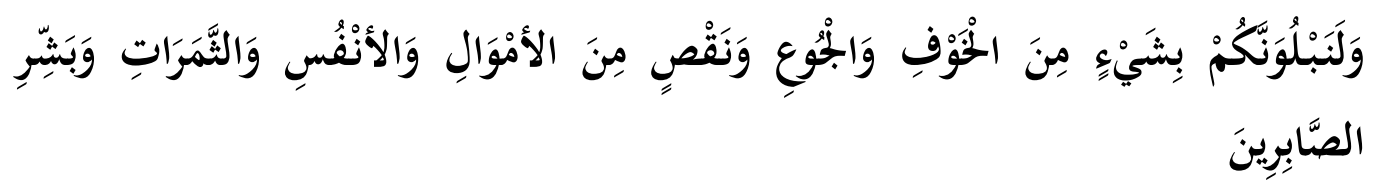

${ }^{12}$ Anwar, Ilmu Tasawuf. . . h.16. 
Artinya: "Dan sungguh akan Kami berikan cobaan kepadamu, dengan sedikit ketakutan, kelaparan, kekurangan harta, jiwa dan buah-buahan. Dan berikanlah berita gembira kepada orang-orang yang sabar". (QS. AlBaqarah [2] :155)

d. Tingkatan Ridha berdasarkan Q.S. Al-Maidah ayat 119 yaitu:

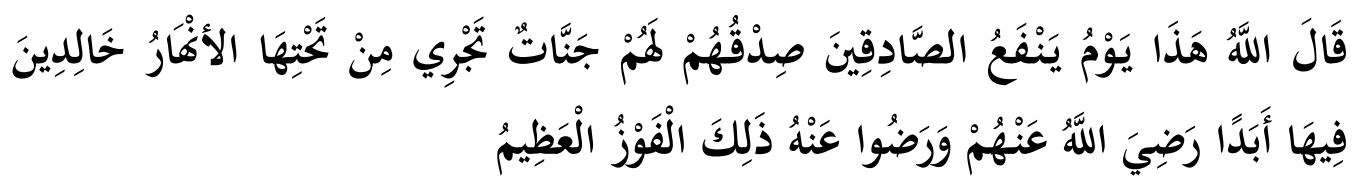

Artinya: "Allah berfirman: "Ini adalah suatu hari yang bermanfaat bagi orangorang yang benar kebenaran mereka. Bagi mereka surga yang dibawahnya mengalir sungai-sungai; mereka kekal di dalamnya selama-lamanya; Allah rida terhadap mereka dan mereka pun rida terhadap-Nya. Itulah keberuntungan yang paling besar". (QS. AlMaidah [5] : 119)

Demikianlah sebagian ayat-ayat Alquran yang dijadikan para sufi sebagai landasan untuk melaksanakan praktek-praktek kesufiannya. Akan tetapi masih banyak ayat-ayat yang lain yang tidak penulis cantumkan.

\section{Riwayat Ibnu Qayim Al-Jauziyah}

Bagi yang telah akrab dengan kehidupan Ibnu Qayim, tahu kehidupannya bagaikan pohon yang memiliki akar dan cabang yang seimbang. Pohon itu hidup dengan makanan yang bersih dan tumbuh dengan cabang yang mengarah kesegala arah sehingga menghasilkan buah yang banyak. Sunguh kehidupan yang yang penuh anugerah, sehingga memberikan manfaat dan memberikan buah yang melimpah.

Nama lengkapnya adalah Mụammad Bin Abi Bakar Bin Ayub bin Sa'ad ArRuz I Ad-Dimasqī, Abū Abdillāh, Syamsuddin. Lahir pada tahun 691 Hijriah dan berguru pada Ash-Shihāb An-Nabilisī Al-‘Ābid dan Qadhī Taqiyuddìn Sulaimān, Faitimah bintu Jauhar, 'Isā al-Muthim, Abū Bakar Ibnu'Abd Ad-daim dan Kepada para jamah, sehingga benar-benar memahami ajarannya untuk menggantikan posisi gurunya Syaikh Taqiyuddin ${ }^{13}$.

Ia telah diuji berkali-kali dan diasingkan oleh gurunya Syaikh Taqiyuddin Ibnu Taimiyah dalam sebuah kamar ketika mendapatkan materi terakhir darinya dan tidak diperkenankan keluar hingga Ibnu Taimiyah meninggal dunia. Selama masa pengasingan itu, ia menghabiskan waktunya untuk membaca Alquran, merenung dan berpikir, sehingga Allah banyak membukakan pintu kebaikan kepadanya dan membukakan kepekaan rasa dan temuan-temuan kebenaran sehingga itu ia sangat menguasai ilmu para ahli ma'rifat dan masuk kedalam relung-relung keilmuan mereka, dan seluruh tulisan-tulisannya dipenuhi masalah-masalah tersebut. Ia telah melaksanakan haji dan berkunjung ke Mekah berkali-kali. Penduduk Mekah merasa

${ }^{13}$ Ibnu Qayyim Al-Jauziyah, Al-Fawa'id (Menuju Pribadi Takwa), (Jakarta: Pustaka Al-Kautsar, 2005), h. XV. 
takjub dan selalu mengenangnya karena ketekunan beribadah dan tekadnya yang kuat untuk melakukan ibadah tawaf.

Banyak orang yeng menimba ilmu darinya ketika usia ia telah senja hingga meninggal dunia. Para ulama besarpun banyak yang menghargai dan mengirim salam kepadanya.

Ibnu Qayim meninggal dunia pada waktu isa hari kamis tanggal 13 Rajab tahun 751 Hijriah. Kemudian dishalatkan esok harinya setelah zuhur dan dikubur dikeburan Al-Bāb Ash-Shaqhïr, yang disaksikan oleh banyak orang.

Ibnu Qayim telah berguru kepada ibnu Taimiyah, menyerap seluruh ilmunya, berdialog dengannya serta menjaganya. ${ }^{14}$

Banyak pemikir dan ulama yang memisahkan antara teori dan praktek, artinya apa yang ditulis dan dikatakan adalah sesuatu, sedangkan apa yang dikerjakan dan dipraktekan dalam kehidupan sehari-hari adalah sesuatu yang lain. Para ulama dan pemikir yang memiliki pendapat semacam ini bukanlah ulama dan pemikir yang pat ut diteladani. Maka, orang yang patut diteladani adalah orang yang memiliki keseimbangan antara ilmu dan amal atau antara teori dan praktek.

Para penulis sejarah dan pemikir Islam tahu bahwa Imam Ibnu Qayim termasuk ulama dan pemikir yang memadukan antara teori dan praktek antara ilmu dan amal. Hal ini dapat dilihat dari tulisan-tulisan Ibnu Qayim disatu sisi dan sejarah kehidupan disisi lain,keduanya memiliki kesamaan dan keserasian antara pemikiran dan praktek atau antara perkataan dan perbuatan.

Ibnu Katsīr pernah berkomentar tentang Ibnu Qayim, ia mengatakan: "Ibnu Qayim memiliki bacaan dan tabiat yang baik, mencintai sesama manusia, tidak pernah dengki kepada orang lain, tidak pernah menghina, tidak pernah menyebarkan aibnya dan tidak pernah iri kepada siapapun. Saya termasuk orang yang paling dekat dengannya. Saya tidak pernah menemukan pada masa kami, orang yang paling banyak ibadahnya dibandingkan dengannya."

\section{Konsep Tasawuf dalam Pemikiran Ibnu Qayyim \\ Mengambil Manfaat Sebanyak-banyaknya dari Alquran ${ }^{15}$}

Jika seseorang ingin mengambil banyak manfaat dari Alquran, maka hayatilah dengan hati ketika ia membaca dan mendengarkannya. Pasang telinga dan jadilah ia seakan-akan hadir dihadapan orang yang diajak bicara oleh Allah, karena sesungguhnya ayat Alquran ditujukan kepada manusia melalui lisan Rasul-Nya. Allah Swt berfirman dalam Q.S. Qaaf: 37:

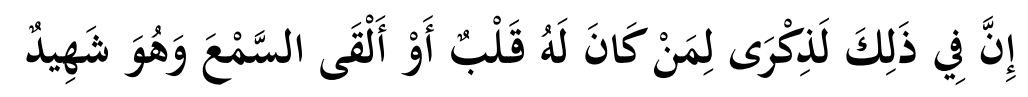

Artinya: "Sesungguhnya pada yang demikian itu benar-benar terdapat peringatan bagi orang-orang yang mempunyai hati atau yang menggunakan pendengarannya, sedang dia menyaksikannya”. (QS. Qaaf [50] : 37)

\footnotetext{
${ }^{14}$ Ibnu Qayyim Al-Jauziyah, Al-Fawa'id (Menuju Pribadi Takwa), h. xvi.

${ }^{15}$ Ibnu Qayyim Al-Jauziyah, Al-Fawa'id (Menuju Pribadi Takwa), h. 1.
} 
Menurut ayat diatas, pengaruh al-Quran akan benar-benar meresap kepada pembacanya, jika ia sepenuhnya tunduk dan patuh kepada pemberi pengaruh, menerima apa adanya sebagai syarat untuk mendapatkan pengaruh, dan menolak segala sesuatu yang menjadi penghalangnya. ${ }^{16}$

Firman Allah"Sesungguhnya pada yang demikianitu benar-benar terdapat peringatan" merupakan isyarat bagi pemberi pengaruh, yaitu Allah.Sedangkan firmannya "bagi orang-orang yeng mempunyai hari" menjelaskan tentang orang-orang yang menerima apa adanya. Maksudnya adalah hati yang hidup yang senantiasa berpikir tentang Allah.

Firmannya "atau mengunakan pendengarannya" berarti memasang telinga atau mendengarkan secara sungguh-sungguh apa yang dikatakan kepadanya. Ia merupakan syarat untuk menyerap pengaruh dari suatu perkataan.

Adapun kata "sedangkan ia menyaksikannya" berarti hatinya hadir ketika membaca Alquran dan tidak mengawang kemana-mana.

Ibnu Qutaibah mengatakan, "yang dimaksud dengan mendengarkan kitab Allah adalah hatinya dan memahaminya, bukan lupa dan terlena karena faktor yang menghalangi munculnya pengaruh itu adalah kelupaan dan keterlenaan hati untuk memikirkan apa yang dikatakan kepadanya serta tidak memikirkan dan merenungkannya."

Jika ada yang memberi pengaruh, Alquran ada pula yang menerimanya dengan apa adanya, hati yang hidup namun harus terpenuhi syarat-syaratnya, yaitu mendengarkan serta membuang segala sesuatu yang menjadi penghalang,yaitu lupa dan keterlenaan terhadap sesuatu yang lain, maka akan muncul pengaruh itu, yaitu dapat mengambil manfaat sebanyak-banyaknya dari Alquran dan memikirkannya.

Jika dikatakan apabila pengaruh itu dapat diperoleh manakala terpenuhi beberapa unsur diatas, lalu apa yang dimaksud dari kata "atau" dalam firman-Nya "atau mengunakan pendengaran" adalah berarti "pengumpul" bukan makna "atau" dalam arti memilih antara dua hal?

Ibnu Qayim menjawab bahwa kata "atau” disini sesuai dengan keadaan orang yang diajak bicara, karena diantara manusia ada yang hatinya hidup dan penuh kesucian. Jika dia bertafakur dengan hatinya dan berfikir dengan fikirannya, maka akal dan hatinya akan menegaskan kebenaran Alquran, karena Alquran adalah haq, dan hatinya akan membenarkan apa yang diberitakan Alquran sehingga turunnya Alquran kepada hatinya menjadi cahaya yang menerangi cahaya fitrah ${ }^{17}$. Inilah sifat orang yang beriman dalam Q.S. Saba': 6 dijelaskan bahwa:

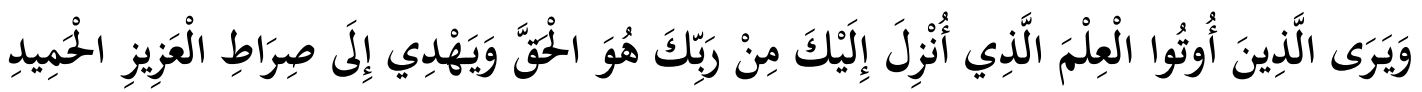

Artinya: "Dan orang-orang yang diberi ilmu (Ahli Kitab) berpendapat bahwa wahyu yang diturunkan kepadamu dari Tuhanmu itulah yang benar dan menunjuki

${ }^{16}$ Ibnu Qayyim Al-Jauziyah, Al-Fawa’id (Menuju Pribadi Takwa), h.2.

${ }^{17}$ Ibnu Qayyim Al-Jauziyah, Al-Fawa'id (Menuju Pribadi Takwa), h. 3. 
(manusia) kepada jalan Tuhan Yang Maha Perkasa lagi Maha Terpuji”. (QS. Saba' [34] : 6)

Mengenai mereka itu Allah juga berfirman dalam Q.S. An Nur: 35,

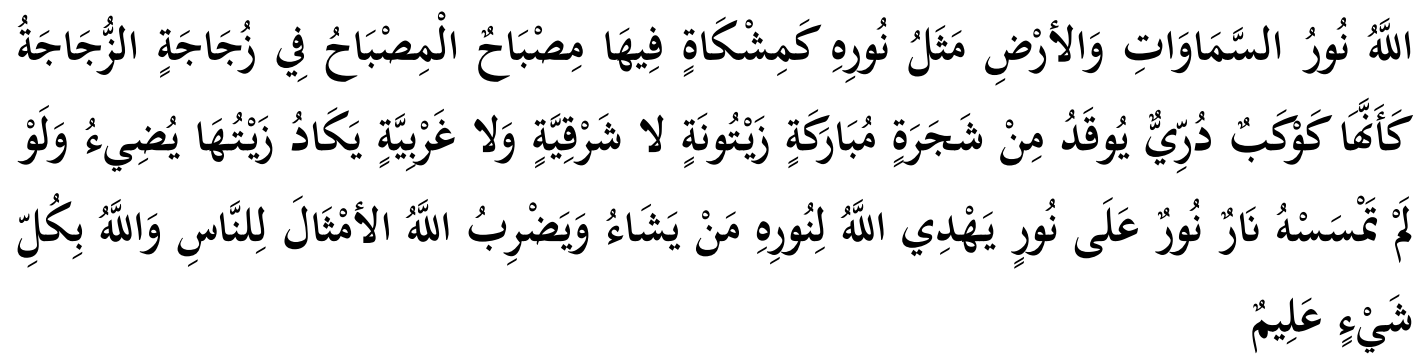

Artinya: "Allah (Pemberi) cahaya (kepada) langit dan bumi. Perumpamaan cahaya Allah, adalah seperti sebuah lubang yang tak tembus, yang di dalamnya ada pelita besar. Pelita itu di dalam kaca (dan) kaca itu seakan-akan bintang (yang bercahaya) seperti mutiara, yang dinyalakan dengan minyak dari pohon yang banyak berkahnya, (yaitu) pohon zaitun yang tumbuh tidak di sebelah timur (sesuatu) dan tidak pula di sebelah barat (nya), yang minyaknya (saja) hampir-hampir menerangi, walaupun tidak disentuh api. Cahaya di atas cahaya (berlapis-lapis), Allah membimbing kepada cahayaNya siapa yang Dia kehendaki, dan Allah memperbuat perumpamaanperumpamaan bagi manusia, dan Allah Maha Mengetahui segala sesuatu”. (QS. An-Nur [24] : 35)

Begitulah kedudukan cahaya fitrah atas cahaya wahyu dan begitu pulalah keadaan orang-orang yang hatinya selalu hidup terjaga.

Ibnu Qayyim berkata, "rahasia yang terkandung dalam ayat diatas telah dipaparkan dalam kitab Ijtima'u Al-Juyus Al-Islamiyah 'Ala Ghazwi Al-Mu'atallah wa Al-Jamiyah"l8

Orang yang memilliki hati yang hidup akan memadukan antara hati dan makna Alquran.Ia merasa seakan-akan Alquran telah tertulis didalam hatinya, sehingga ia dapat menghafalkan diluar kepala.

Diantara manusia juga ada yang tidak memiliki kesiapan yang penuh, hatinya mati, dan hidupnya morat-marit, sehingga membutuhkan bantuan orang lain untuk membedakan antara yang haq dan yang bătil. Orang tersebut kehidupan dan cahaya hatinyatidak dapat disamakan dengan orang yang hatinya hidup dan terjaga. Adapun cara untuk mendapatkan hidayah dengan terus menerus mendengarkan pembacaan alQuran, bertadabur dan bertafakur atas kalam Allah tersebut. Ini akan membukakan kesadaran kepadanya akan kebenaran al-Quran.

Pertama, adalah orang yang mengetahui dengan pasti terhadap apa yang diserukan dan diberitakan kepadannya, maka orang ini berada dalam maqām ịhsan.

Kedua, adalah orang yang mengetahui kebenaran apa yang dikabarkan kepadanya dan meyakininya, lalu berkata, cukup bagi yang mendengar berita ini. Maka orang ini

\footnotetext{
${ }^{18}$ Ibid., h.
} 
berada dalam maqām iman. Kedua peringkat ini bisa dikatakan telah sampai kepada 'ilmu al-Yaqīn'19.

Dari tingkat 'ilmu al-yaqīn kemudian hatinya bergerak meningkat kapada 'Ain Al-Yaqīn, yaitu orang yang percaya dengan sepenuh hati kepada Alquran, lalu keluar dari kekufuran dan masuk sepenuhnya kepada ajaran Islam.

'Ain al-yaqīn dibagi menjadi dua bagian: bagian pertama didunia dan bagian kedua di akhirat. Hasil dari pengetahuan 'Ain al-yaqīn didunia adalah bahwa ia dapat melihat dengan mata hatinya seperti halnya ia melihat dengan kedua matannya. Segala berita ghaib yang dikabarkan oleh Rasul seakan-akan ia dapat melihatnya langsung dengan kedua matanya di dunia. Inilah dua martabat dari 'Ain al-yaqīn.

\section{Merenungkan Kandungan Alquran}

Dengan merenungi kandungan al-Quran, seseorang akan menemukan Penguasa yang menguasai seluruh kerajaan dan memiliki segala puji. Semua perkara berada ditangan-Nya, berasal dari padan-Nya dan kembali kepada-Nya, dia duduk diatas singgasana-Nya, menguasai seluruh kekuasaan-Nya, mengetahui apa yang ada didalam jiwa para hamba-Nya dan mengetahu rahasi mereka. Dia sendiri yang mengatur kerajaan, mendengar, melihat, memberi, menolak, memberi pahala dan siksa, memuliakan, menghinakan, menciptakan, memutuskan dan memelihara. Semua perkara bisa diatasi-Nya baik yang kecil maupun yang besar. Bahkan sebuah biji tidak akan bergerak kecuali mendapat ijin dari-Nya dan sehelai daun tidak akan jatuh kecuali at as pengetahuan-Nya.

\section{Hati dan Akal}

Ibnu Qayyim membagi hati kepada tiga macam tipe; hati yang sehat, hati yang sakit dan hati yang mati. Pertama, hati yang sehat, yaitu hati yang bersih yang seorangpun tidak akan bisa selamat tanpanya. Sebagaimana firman Allah: "(yaitu) di hari harta dan anak-anak laki-laki tidak berguna, kecuali orang-orang yang menghadap Allah dengan hati yang bersih..." (Asy-Syuara; 88-89)

Kedua, Tipe hati yang kedua adalah hati yang hidup tetapi cacat. Ia memiliki dua materi yang saling tarik menarik antara kecintaan kepada Allah keimanan dan keikhlasan dengan cinta kepada nafsu keinginan dan usaha untuk mendapatkannya, disertai dengan sikap sombong dan bangga diri.

Ketiga, Tipe hati yang ketiga adalah hati yang mati yang tidak ada kehidupan didalamnya. Ia tidak mengetahui tuhannya dan tidak menyembahnya, bahkan selalu menuruti keinginan hawa nafsu dan kelezatan dirinya, inilah hati orang yang kufur ${ }^{20}$.

Hati adalah wadah atau tempat untuk mempengaruhi kekhusyuan. Ibnu Qayyim berkata:

${ }^{19}$ Ibnu Qayyim Al-Jauziyah, Al-Fawa'id (Menuju Pribadi Takwa), (Jakarta: Pustaka Al-Kautsar, 2005), h. 4.

${ }^{20}$ Ibnu Qayyim al-Jauziah, Managemen Qalbu, Melumpuhkan Senjata Syetan, (Jakarta; Darul Falah, 2008), h. 
"sebenarnya khusyu itu adalah sebuah makna yang tersarikan dari sikap hormat, cinta, rendah hati, dan pasrah hati"'21.

"Sesungguhnya jika nafsu meluas maka hati akan menyempit sehingga kehidupan menjadi sempit, namun sebaliknya, jika hawa nafsu menyempit maka hati akan menjadi lapang dan luas dan kehidupan akan berbahagia" katanya lagi.

Akal adalah timbangan setiap ilmu untuk mengetahui yang benar dan yang salah. Akal terbagi dua yaitu akal insting yang merupakan pemelihara dan penghasillmu. Kedua akal muktasab dan mustafad yang merupakan hasil ilmu. Jika kedua akal tersebut menyatu maka itu adalah keutamaan dan kebahagiaan.

\section{Kesimpulan}

Alquran dijadikan sebagai dasar-dasar para sufi dalam bertasawuf. Kedudukannya sebagai ilmu tentang tingkatan (maqam) dan keadaan (ahwal). Selain Alquran, Hadis juga merupakan landasan dalam tasawuf sebagaimana yang pernah dilakukan oleh Rasulullah di Gua Hira, yaitu tafakkur, beribadah, dan hidup sebagai seorang zahid, Beliau hidup sangat sederhana, terkadang mengenakan pakaian tambalan, tidak makan dan minum kecuali yang halal, dan setiap malam senantiasa beribadah kepada Allah SWT.

Dikalangan para sahabat juga banyak yang mempraktekkan tasawuf sebagaimana yang dipraktekkan oleh Nabi Muhammad SAW. Untuk menjadi seorang sufi, seseorang harus bisa meninggalkan segala yang menyangkut dengan sifat kebendaan dan senantiasa bertaubat serta mendekatkan diri kepada-Nya untuk mencapai ridha Allah SWT.

Dalam bertasawuf dapat dilakukan dengan metode Qur'ani yang dilakukan oleh Ibnu Qayyim Al-Jauziyah dimana ajarannya dapat mendekatkan kita kepada penyucian jiwa yang lebih baik.

\footnotetext{
${ }^{21}$ Ibnu Qayyim al-Jauziah, Sepuluh Kekasih Allah; Terjemah, (Jakarta: Pustaka Azaam, 2000), h. 118.
} 


\section{DAFTAR PUSTAKA}

Al-Jauziah, IbnuQayyim, SepuluhKekasih Allah; Terjemah, Jakarta: PustakaAzaam, 2000.

------------------, Al-Fawa'id (Menuju Pribadi Takwa), Jakarta: Pustaka Al-Kautsar, 2005.

DarulFalah, 2008.

ManagemenQalbu, MelumpuhkanSenjataSyetan, Jakarta;

Tasawuf, Bandung: Pustaka Setia, 2006

Departemen Pendidikan, Kamus Besar Bahasa Indonesia, Balai Pustaka, 1990.

Nata, Abuddin, Akhlak Tasawuf Cet. I, Jakarta; Raja Grafindo Persada, 2006.

Rahmat, Jalaluddin, Meraih Cinta Ilahi ; Pencerahan Sufistik, Bandung : Remaja Rosdakarya, 2001.

Shihab, Quraish, Tafsir al-Misbah, Jakarta : Lentera Hati, 2001.

https://syairiblog.blogspot.co.id/2015/04/makalah-islam-dan-tasawuf.html tanggal 6 Februari 2018. 